\title{
PERILAKU KONSUMSI SUMBER ENHANCER DAN INHIBITOR FE DENGAN ANEMIA PADA KEHAMILAN
}

\author{
Juhrotun Nisa'), Adevia Maulidya Chikmah'2), Evi Zulfiana ${ }^{3)}$ \\ nisa.jn20@gmail.com \\ ${ }^{1,2,3)}$ Prodi D3 Kebidanan Politeknik Harapan Bersama \\ J1. Mataram No. 9 Pesurungan Lor Tegal
}

\begin{abstract}
Anemia is a deficiency of hemoglobin levels, hematocrit and the number of erythrocytes lower than normal. Nutritional anemia is influenced lack of iron in food del absorption of iron is low, increasing demand, dietary deficiency, and there are inhibitors of iron absorption in the diet. To increase the absorption of nutrients there are several micronutrients that can be consumed along with fe, which are also called enhancer factors, but there are also some substances that can inhibit absorption (inhibitors). This study aims to determine the consumption behavior of Fe enhancers and $\mathrm{Fe}$ inhibitors with the incidence of anemia in pregnancy. This research is analytical survey research with cross sectional research design. conducted during August 2018 in Margadana Village, Tegal City. All pregnant women from April to July in Margadana Village are used as samples. Data analysis using chi square. The results showed that there was no relationship between vegetable eating behavior $(P=0.58)$, eating fruit $(P=0.57)$, eating frequency (0.42)and tea drinking habits during pregnancy on the incidence of anemia $(P=0.7)$, but there was a relationship between fruit consumption behavior before pregnancy and the incidence of anemia $(P=0.036)$. Mentoring and monitoring of consumption patterns in pregnant women, especially those with anemia, need to be done.
\end{abstract}

Keyword: Anemia, an enhancer factor, an inhibitor factor

\begin{abstract}
Abstrak
Anemia adalah suatu keadaan adanya penurunan kadar hemoglobin, hematokrit dan jumlah eritrosit di bawah nilai normal. Anemia gizi dipengaruhi oleh jumlah zat besi dalam makanan yang tidak cukup, penyerapan zat besi rendah, kebutuhan meningkat, pola makan tidak baik, dan terdapat zat penghambat penyerapan zat besi dalam makanan. Untuk meningkatkan penyerapan zat gizi terdapat beberapa zat gizi mikro yang dapat dikonsumsi bersama dengan fe yang disebut juga faktor enhancer, tetapi terdapat juga beberapa zat dapat menghambat penyerapan (inhibitor). Tujuan penelitian ini untuk mengetahui perilaku konsumsi sumber enhancer Fe dan inhibitor Fe dengan anemia pada kehamilan.

Penelitian ini adalah penelitian survey analitik dengan pendekatan crosssectional. yang dilakukan selama bulan Agustus 2018 di Kelurahan Margadana Kota Tegal. Seluruh ibu hamil selama bulan April sampai Juli di Kelurahan Margadana dijadikan sebagai sampel. Analisia data menggunakan chi square.

Hasil penelitian menujukan bahwa perilaku makan sayur $(P=0.58)$, makan buah selama hamil $(P=0.57)$, frekuensi makan $(P=0.42)$ dan kebiasaan minum teh selama hamil $(P=0.7)$ tidak berhubungan dengan anemia, tetapi perilaku konsumsi buah sebelum hamil berhubungan dengan anemia $(P=0.036)$. Perlu dilakukan pendampingan maupun pemantauan pola konsumsi pada ibu hamil khususnya yang mengalami anemia.
\end{abstract}

Kata kunci: Anemia, faktor enhancer, faktor inhibitor

\section{Pendahuluan}

Anemia merupakan suatu keadaan adanya penurunan kadar hemoglobin, hematokrit dan jumlah eritrosit di bawah nilai normal. Pada penderitan anemia, lebih sering disebut kurang darah, kadar sel darah merah (hemoglobin/Hb) dibawah nilai normal. ${ }^{[1]} \mathrm{Hb}$ merupakan zat yang berfungsi mengangkut oksigen ke seluruh jaringan tubuh termasuk ke tubuh janin yang dikandung oleh ibu, sehingga jika terjadi anemia pada ibu 
hamil, maka proses pengangkutan oksigen ke seluruh tubuh tersebut akan mengalami gangguan. ${ }^{[2]}$

Wanita yang memiliki cadangan zat besi rendah pada saat awal kehamilan memiliki risiko mengalami anemia defisiensi besi yang cukup besar dikarenakan kebutuhan tubuh terhadap mineral besi meningkat secara substansial dengan bertambahnya umur kehamilan. Kebutuhan zat besi wanita hamil lebih dari 90\%, kebutuhan tersebut saat kehamilan trimester kedua dan ketiga, yaitu setara dengan $5.5 \mathrm{mg}$ zat besi setiap harinya. ${ }^{[3]}$

Risiko kesakitan pada ibu hamil yang mengalami anemia lebih besar dibandingkan dengan ibu hamil normal, terutama pada trimester ke tiga kehamilan. ${ }^{[4]}$ Dampak yang terjadi pada ibu hamil yang mengalami anemia yaitu berisiko besar melahirkan bayi dengan BBLR, selain itu juga berisiko mengalami perdarahan karena kondisinya lemah dan terdapat gangguan kesehatan yang bahkan dapat mengakibatkan kematian baik ibu maupun bayinya terutama pada ibu yang menderita anemia berat. Pernyataan tersebut sejalan dengan penelitian yang dilakukan Umriaty dan Nisa, J (2018) yang menyatakan bahwa "terdapat hubungan yang signifikan antara anemia dengan berat badan lahir rendah". ${ }^{[5]}$

Menurut WHO kejadian anemia kehamilan secara global adalah 51\%, sedangkan anemia pada wanita secara keseluruhan adalah 35\%. ${ }^{[6]}$ Di Indonesia angka kejadian anemia pada ibu hamil adalah $37.1 \%$ dengan kadar Hb kurang dari $11.0 \mathrm{gram} / \mathrm{dl}$, dengan proporsi yang hampir sama antara di kawasan perkotaan (36.4\%) dan pedesaan $(37.8 \%) .^{[7]}$

Beberapa faktor yang mempengaruhi anemia diantaranya adalah jumlah zat besi yang tidak cukup dalam makanan, rendahnya penyerapan zat besi, peningkatan kebutuhan, kekurangan darah, pola makan yang tidak baik, status sosial ekonomi, adanya penyakit infeksi dan rendahnya pengetahuan tentang zat besi, selain itu adanya zat penghambat penyerapan zat besi yang berasal dari makanan. ${ }^{[8]}$ Asupan makanan yang dikonsumsi penting untuk dilihat nilai faktor enhancer (faktor pendorong) dan inhibitor (faktor penghambat) dalam penyerapan zat besi (fe). Untuk meningkatkan penyerapan zat gizi terdapat beberapa zat gizi mikro yang dapat dikonsumsi bersama dengan fe yang disebut juga faktor enhancer seperti vitamin $\mathrm{A}$, dan vitamin $\mathrm{C}$ yang terkandung dalam buah dan sayur, akan tetapi terdapat beberapa zat juga yang dapat menghambat penyerapan (inhibitor) zat besi seperti zat tannin yang terdapat pada teh dan kopi, makanan yang mengandung kalsium, fosfat dan fitat yang dikonsumsi dalam jumlah banyak juga dapat menghambat penyerapan zat besi tersebut. ${ }^{[9]}$

Adanya pengaruh pola makan dengan anemia pada kehamilan menunjukan bahwa perlunya pencegahan dan perawatan dengan perbaikan pola dan kebiasaan makan terutama makanan dengan gizi seimbang. Dari 15 Ibu hamil yang memiliki pola makan tidak sehat, 7 diantaranya mengalami anemia, ${ }^{[10]}$ sedangkan pratiwi dan widari (2018) mengatakan bahwa "sebagian besar Ibu Hamil Trimester III jarang mengkonsumsi sumber pangan enhancer zat besi $(60.5 \%)$ dan jarang mengkonsumsi inhibitor zat besi (39.5\%), serta responden yang mengalami anemia juga cukup tinggi (41.9\%)". ${ }^{[11]}$

Berdasarkan data di atas maka penelitian ini dilakukan dengan tujuan untuk mengetahui perilaku konsumsi sumber enhancer $\mathrm{Fe}$ (frekuensi makan dalam sehari, makan buah sebelum hamil, makan buah selama hamil, dan makan sayur selama hamil), dan inhibitor $\mathrm{Fe}$ (minum teh) dengan anemia pada kehamilan.

\section{Metode Penelitian}

Penelitian ini merupakan penelitian kuantitatif non experimental, menggunakan desain observasional analitik dengan cross sectional study, yaitu rancangan penelitian dengan 
melakukan pengukuran atau pengamatan pada saat bersamaan (sekali waktu) antara faktor risiko/paparan dengan penyakit. Dilakukan pada bulan Agustus dengan populasi seluruh ibu hamil di Kelurahan Margadana dari bulan April sampai Juli 2018. Menggunakan total sampling dengan jumlah sampel 38 orang ibu hamil.

Variabel dependen yaitu anemia pada kehamilan, data anemia/tidak anemia berasal dari buku KIA yang dimiliki ibu berdasarkan pemeriksaan hemoglobin terakhir, sedangkan variabel independen terdiri dari frekuensi makan dalam sehari, konsumsi buah dan sayur selama hamil, konsumsi buahsebelum hamil, serta minum teh selama hamil.

Instrumen penelitian yang digunakan adalah kuesioner sedangkan pengolahan dan analisia data menggunakan program Statistical Package for Social Science (SPSS) dengan chi square.

\section{Hasil dan Pembahasan}

Penelitian ini dilakukan pada ibu hamil di Kelurahan Margadana sejumlah 38 responden. Responden yang mengalami anemia sejumlah 29 orang, dan 9 orang ibu hamil lainnya memiliki kadar hemoglobin (hb) yang normal. Adapun karakteristik responden lainnya dapat dilihat pada tabel berikut.

Tabel 1 Distribusi Frekuensi Gambaran Karakteristik Responden

\begin{tabular}{llcl}
\hline No & \multicolumn{1}{c}{ Variabel } & F & $\%$ \\
\hline 1. & Hemoglobin & & \\
& $\bullet \quad$ Anemia & 29 & $76.3 \%$ \\
& $\bullet \quad$ Tidak Anemia & 9 & $23.5 \%$ \\
2. & Umur ibu & & \\
& $\bullet \quad>35$ tahun dan $<20$ & 8 & $21.1 \%$ \\
& $\quad$ tahun & 30 & $78.9 \%$ \\
& $\bullet \quad$ 20-35 tahun & & \\
3. Paritas & & \\
& $\bullet \quad$ Primigravida & 10 & $26.3 \%$ \\
& $\bullet \quad$ Multigravida & 28 & $73.7 \%$ \\
4. Pendidikan Ibu & & \\
& $\bullet \quad<$ SMA & 28 & $73.7 \%$ \\
& $\bullet \quad \geq$ SMA & 10 & $26.7 \%$
\end{tabular}

5. Umur kehamilan

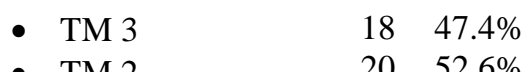

- $\mathrm{TM} 2 \quad 20 \quad 52.6 \%$

6. Pendapatan keluarga

- $<$ UMR $923.7 \%$

- $\geq$ UMR $29 \quad 76.3 \%$

Responden yang mengalami anemia sebanyak $76.3 \%$, hasil tersebut menunjukan bahwa masih banyak ibu hamil yang membutuhkan perhatian untuk mengurangi angka kesakitan dan kematian yang disebabkan komplikasi penyakit tersebut. Responden sebagian besar memiliki usia reproduktif 20-35 tahun $78.9 \%$, ibu multigravida sebanyak $73.7 \%$, pada ibu multigravida cenderung kurang memperhatikan nutrisi pada kehamilan kedua dan seterusnya, sehingga anemia banyak terjadi pada kehamilan lebih dari satu, hal ini sejalan dengan penelitian Ariyani yang mengatakan bahwa sebagian besar respondennya pada paritas aman (13). ${ }^{[12]}$

Pendidikan kurang dari SMA sebanyak $73.7 \%$, rendahnya tingkat pendidikan dapat mempengaruhi tingkat kesadaran responden tentang kesehatan, penelitian lisnawati dan ediana juga menunjukan sebagian besar responden penelitiannya berpendidikan kurang dari SMA. ${ }^{[13]}$

Usia kehamilan ibu di trimester 2 sebanyak $52.6 \%$ hanya memiliki sedikit selisih dengan trimester 3 yaitu $47.4 \%$, hal tersebut dikarenakan terjadinya anemia dalam kehamilan dimulai pada usia kehamilan trimester 2 dan puncaknya terjadi pada awal trimester 3 . Pada kehamilan terjadi hemodilusi dengan peningkatan volume darah $30 \%$ sampai $40 \% .^{[14]}$

Pendapatan keluarga lebih dari upah minimum regional (UMR) sebanyak $76.3 \%$. Pendapatan keluarga yang dimiliki oleh responden seharusnya dapat memenuhi kebutuhan nutrisi ibu hamil untuk mencegah kejadian anemia, tetapi dengan pendapatan yang melebihi UMR responden justru memiliki kesempatan lebih banyak untuk tidak memasak makanan sendiri dan memilih 
membelinya di warung, sesuai selera tanpa memperhatikan nutrisi yang diperlukan saat kehamilan terutama zat besi.

\section{Perilaku Konsumsi Sumber Enhancer Fe Dengan Anemia Pada Kehamilan}

Tabel 2 Perilaku Konsumsi Sumber Enhancer Fe Dengan Anemia Pada Kehamilan

\begin{tabular}{|c|c|c|c|c|c|c|c|c|}
\hline \multirow[b]{2}{*}{ No } & \multirow[b]{2}{*}{ Variabel } & \multirow[b]{2}{*}{$\mathbf{F}$} & \multirow[b]{2}{*}{$\%$} & \multicolumn{2}{|c|}{ Anemia } & \multicolumn{2}{|c|}{ Tidak Anemia } & \multirow[b]{2}{*}{$\mathbf{P}$} \\
\hline & & & & $\mathbf{F}$ & $\%$ & $\mathbf{F}$ & $\%$ & \\
\hline 1. & $\begin{array}{l}\text { Frekuensi makan } \\
-\quad<3 \text { kali } \\
-\quad \geq 3 \text { kali }\end{array}$ & $\begin{array}{l}2 \\
36\end{array}$ & $\begin{array}{l}5.3 \% \\
94.7 \%\end{array}$ & $\begin{array}{l}2 \\
27\end{array}$ & $\begin{array}{c}100 \% \\
75 \%\end{array}$ & $\begin{array}{l}0 \\
9\end{array}$ & $\begin{array}{c}0 \\
25 \%\end{array}$ & 0.42 \\
\hline 2. & $\begin{array}{l}\text { Konsumsi buah } \\
\text { selama hamil } \\
\text { - Jarang } \\
\text { - Setiap hari }\end{array}$ & $\begin{array}{l}20 \\
18\end{array}$ & $\begin{array}{l}52.6 \% \\
47.4 \%\end{array}$ & $\begin{array}{l}16 \\
13\end{array}$ & $\begin{array}{l}80 \% \\
72.2 \%\end{array}$ & $\begin{array}{l}4 \\
5\end{array}$ & $\begin{array}{l}20 \% \\
27.8 \%\end{array}$ & 0.57 \\
\hline 3. & $\begin{array}{l}\text { Konsumsi buah } \\
\text { sebelum hamil } \\
\text { - Tidak } \\
\text { - Ya }\end{array}$ & $\begin{array}{l}9 \\
29\end{array}$ & $\begin{array}{l}23.7 \% \\
76.3 \%\end{array}$ & $\begin{array}{l}9 \\
20\end{array}$ & $\begin{array}{l}100 \% \\
69 \%\end{array}$ & $\begin{array}{l}0 \\
9\end{array}$ & $\begin{array}{l}0 \\
31 \%\end{array}$ & 0.036 \\
\hline 4. & $\begin{array}{l}\text { Konsumsi sayur } \\
\text { - Jarang } \\
\text { - Setiap hari }\end{array}$ & $\begin{array}{l}10 \\
28\end{array}$ & $\begin{array}{l}26.3 \% \\
73.7 \%\end{array}$ & $\begin{array}{l}7 \\
22\end{array}$ & $\begin{array}{l}70 \% \\
78.6 \%\end{array}$ & $\begin{array}{l}3 \\
6\end{array}$ & $\begin{array}{l}30 \% \\
21.4 \%\end{array}$ & 0.58 \\
\hline
\end{tabular}

Sebagian besar responden memiliki frekuensi makan lebih dari 3 kali dalam satu hari yaitu sebsar $94.7 \%$, hal tersebut dipengaruhi oleh peningkatan kebutuhan gizi saat ibu mengandung, sehingga ibu lebih mudah dan cepat lapar. Ibu yang biasanya hanya makan untuk kebutuhan sendiri, saat mengandung ia juga harus memenuhi kebutuhan nutrisi bayi dan dirinya, WHO menganjurkan jumlah tambahan sebesar 150 Kkal sehari pada trimester I, dan $350 \mathrm{Kkal}$ sehari pada trimester II dan III. ${ }^{[15]}$

Frekuensi makan tidak berhubungan dengan anemia kehamilan (nilai $P$ value: 0.42 ). Perilaku responden yang membeli makanan dari luar rumah, tanpa memperhatikan kandungan gizi yang terdapat dalam makanan berdampak pada kejadian anemia. Hasil penelitian tersebut bertentangan dengan penelitian yang dilkaukan oleh Chaeril (2017) yang menunjukan bahwa "ibu hamil Trimester III dengan pola makan yang cukup dan mengalami anemia sebanyak
12 orang (24.4\%), pola makan yang baik yang tidak mengalami anemia sebanyak 19 orang (38.9\%). Dan terdapat hubungan antara pola makan dengan kejadian anemia pada ibu hamil Trimester III di Puskesmas Jetis Kota Yogyakarta. ${ }^{[16]}$

Perilaku responden dalam mengkonsumsi Sumber enhancer $\mathrm{Fe}$ yang berasal dari buah sebagian besarjarang makan buah selama hamil yaitu 52.6\%, akan tetapi kebiasaan mengkonsumsi buah sebelum mereka hamil justru lebih besar yaitu $76.3 \%$. Perubahan sistem pencernaan saat ibu mengandung mempengaruhi jenis makanan yang bisa diterima oleh ibu selama hamil, sehingga konsumsi buah saat ibu mengandung justru lebih jarang dibandingkan ketika ibu belum mengandung. Tidak terdapat hubungan antara perilaku konsumsi enhacer $\mathrm{Fe}$ yang berasal dari buah selama ibu hamil, tetapi terdapat hubungan yang signifikan antara perilaku konsumsi buah sebelum 
hamil dengan kejadian anemia, hal tersebut dikarenakan kebutuhan gizi ibu telah dipersiapkan sebelum ia hamil, penelitian Pratiwi dan Widari (2018) "Tidak terdapat hubungan antara kebiasaan konsumsi sumber pangan enhancer zat besi dengan kejadian anemia $(\mathrm{p}=0.420)$ ". ${ }^{[1]}$

Tidak mengkonsumsi buah dapat meningkatkan 3.29 kali lebih besar kejadian anemia dibandingkan ibu yang mengkonsumsi buah $[\mathrm{AOR}=3.29,95 \%$ CI: $1.59,6.82]$. Sejalan dengan fakta ini, penelitian ini menunjukkan bahwa kemungkinan anemia meningkat di antara ibu yang tidak memiliki asupan buah pada minggu sebelumnya sebelum tanggal pengumpulan data. ${ }^{[17]}$

Perilaku konsumsi sumber enhancer $F e$ dari sayur pada responden saat hamil sebagian besar sudah mengkonsumsinya setiap hari yaitu $73.7 \%$. Adanya asuhan dari tenaga kesehatan terkait pentingnya mengkonsumsi makanan yang bergizi selama hamil, khususnya sayur-sayuran dapat meningkatkan motivasi ibu untuk mengkonsumsi sayur-sayuran.

Tidak terdapat hubungan antara perilaku konsumsi sumber enhancer $F e$ dari sayur dengan kejadian anemia (nilai $\mathrm{P}: 0.58)$, selain kandungan besi dan vitamin lainnya yang terdapat dalam sayuran, terdapat pula asam oksalat yang dapat menghambat absorbsi besi. ${ }^{[18]} \mathrm{Hal}$ tersebut bertentangan dengan penelitian rahayu dan suryani (2018) yang mengatakan bahwa "Ada hubungan konsumsi sayuran hijau dengan kejadian anemia pada ibu hamil ( $\mathrm{p}=0.004)$, sayuran hijau merupakan unsur kunci dalam susunan menu yang mementingkan kesehatan,sayuran hijau seperti bayam mengandung banyak magnesium dan potassium, dan satu porsi sayuran hijau memberikan 10 sampai $30 \%$ intake harian yang dianjurkan". ${ }^{[19]}$

\section{Perilaku Konsumsi Sumber InhibitorFe Dengan Anemia Pada Kehamilan}

Tabel 3 Perilaku Konsumsi Sumber Inhibitor Fe Dengan Anemia Pada Kehamilan

\begin{tabular}{|c|c|c|c|c|c|c|c|c|}
\hline \multirow[b]{2}{*}{ No } & \multirow[b]{2}{*}{ Variabel } & \multirow[b]{2}{*}{$\mathbf{F}$} & \multirow[b]{2}{*}{$\%$} & \multicolumn{2}{|c|}{ Anemia } & \multicolumn{2}{|c|}{ Tidak Anemia } & \multirow[b]{2}{*}{$\mathbf{P}$} \\
\hline & & & & $\mathbf{F}$ & $\%$ & $\mathbf{F}$ & $\%$ & \\
\hline \multicolumn{9}{|c|}{ Minum teh Selama Hamil } \\
\hline 1. & $\mathrm{Ya}$ & 19 & $50 \%$ & 14 & $73.7 \%$ & 5 & $26.3 \%$ & 0.7 \\
\hline 2. & Tidak/jarang & 19 & $50 \%$ & 15 & $78.9 \%$ & 4 & $21.1 \%$ & \\
\hline
\end{tabular}

Perilaku Konsumsi Sumber Inhibitor Fe yaitu minum teh saat ibu mengandung, pada faktor ini hanya mengkaji kebiasaan minum teh mengingat Tegal merupakan kota yang identik dengan tehnya dan adanya larangan minum kopi pada saat hamil. Jumlah responden yang sering minum teh dengan yang jarang minum teh memiliki besar yang sama. Hal tersebut dipengaruhi karena beberapa ibu justru mengkonsumsi air teh hangat untuk mengurangi mual, sedangkan beberapa ibu justru tidak suka minum teh sejak sebelum hamil, sehingga antara ibu yang minum teh dengan yang tidak/jarang minum teh memiliki proporsi yang sama besarnya.
Tidak terdapat hubungan antara kebiasaan mengkonsumsi/minum teh dengan anemia pada kehamilan (Nilai $\mathrm{P}: 0.7)$. Sejalan dengan penelitian Melorys L. P., dan Galuh N. P (2017) yang menyebutkan bahwa "tidak terdapat hubungan yang signifikan antara kebiasaan minum teh dengan kejadian anemia pada kehamilan". nilai $p$ value 0.953 (>0.05). Kebiasaan minum teh dengan jeda waktu 1 sampai dengan 2 jam sebelum maupun sesudah 1 makan memungkinkan terjadi penyerapan zat besi dalam tubuh dan tidak terjadi penghambatan penyerapan. ${ }^{[20]}$

Mashtalina (2015), menyebutkan bahwa "terdapat hubungan antara konsumsi 
faktor inhibitor $\mathrm{Fe}$ dengan status anemia. Konsumsi bahan pangan yang mengandung zat-zat penghambat absorbsi zat besi harus dikurangi. Adanya zat penghambat penyerapan besi atau inhibitor yang sering dikonsumsi oleh ibu hamil seperti kafein, tanin, oksalat, fitat dapat menyebabkan terhambatnya penyerapan zat besi dalam tubuh. Zat inhibitortersebut harus dihindari karena zat ini mengikat zat besi sehingga tidak dapat diabsorbsi”. [21]

\section{Kesimpulan}

Hasil penelitian menunjukan bahwa perilakukonsumsi buah sebelum hamil berhubungan dengan kejadian anemia, sedangkan frekuensi makan,konsumsi buah dan sayur selama hamil, serta konsumsi teh selama hamil tidak memiliki hubungan dengan kejadian anemia. Perlu dilakukan pendampingan maupun pemantauan pola konsumsi tentang makanan yang mendorong dan menghambat penyerapan zat gizi pada saat ibu hamil khususnya pada ibu yang mengalami anemia.

\section{Daftar Pustaka}

[1] Saifuddin, A.B., Rachimhadhi, T., Wiknjosastro, G.H. Ilmu Kebidanan Sarwono Prawirohardjo. Jakarta: PT Bina Pustaka Sarwono Prawirohardjo; 2014.

[2] Amiruddin, Ridwan. Risiko Asap Rokok Dan Obat-Obatan Terhadap Kelahiran Prematur Di Rumah Sakit St. Fatimah Makassar. Jurnal Medika Nusantara. Jurusan Epidemiologi Fakultas Kesehatan Masyarakat. Universitas Hasanuddin; 2006.

[3] Machado, Carli, Szarfarc, Souza, Fujimori And Colli. Anemia Among Pregnant Women Attending Primary Healthcare Units In The Municipality Of São Paulo, Brazil: Evaluations After The Mandatory Fortification Of Wheat And Maize Flours With Iron. Nutrire. Biomedical Central; 2016: 41:19. Doi 10.1186/S41110-016-0020-Z.
[4] Mardiwiono. Hubungan Tingkat Pengetahuan Ibu Hamil Tentang Anemia Dengan Status Anemia Dalam Kehamilan Di Puskesmas Kalibawang. Artikel Kesehatan; 2009.

[5] Umriaty Dan Nisa, J. Faktor Maternal Yang Mempengaruhi Kejadian Berat Bayi Lahir Rendah (Bblr) Di Kota Tegal. Ji-Kes: Jurnal Ilmu Kesehatan; 2018. Volume 2 No. 1: 67-72.

[6] Aritonang E, Kebutuhan Gizi Ibu Hamil. Ipb Taman Kencana: Ipb Press Kampus. Bogor; 2010.

[7] Riskesda. Riset Kesehatan Dasar. Jakarta: Kementerian Kesehatan: Badan Penelitian Dan Pengembangan Kesehatan; 2013.

[8] Puji A.E, Satriani S, Nadimin, Fadliyah. Hubungan Pengetahuan Ibu Dan Pola Konsumsi Dengan Kejadian Anemia Gizi Pada Ibu Hamil Di Puskesmas Kassi-Kassi. Jurnal Media Gizi Pangan; 2010. Vol. X, Edisi 2.

[9] Sizer, F. S. \& Whitney, E. (13th Ed). Nutrition: Concepts And Controversies. Cengage Learning; 2013.

[10] Mariana, D, Wulandari, D, dan Padila. Hubungan Pola Makan Dengan Kejadian Anemia Pada Ibu Hamil Di Wilayah Kerja Puskesmas. Jurnal Keperawatan Silampari (JKS); 2018. Volume 1, No 2: 108-122.

[11] Pratiwi, R Dan Widari, D. Relation Of Iron Enhancer And Inhibitor Food Consumption With Anemia In Pregnant Women. Amerta Nutr. 2018: 283-291. Doi 10.2473/Amnt.V2i3.2018.283-291

[12] Ariyani, R. Faktor-Faktor Yang Mempengaruhi Kejadian Anemia Pada Ibu Hamil Trimester III Di Wilayah Kerja Puskesmas Mojolaban Kabupaten Sukoharjo. Naskah Publikasi. Surakarta: Program Studi Ilmu Gizi Fakultas Ilmu Kesehatan Universitas Muhammadiyah Surakarta; 2016. 
[13] Liswanti, Y Dan Ediana, D. Hubungan Pengetahuan, Sikap Dan Perilaku Konsumsi Zat Besi (Fe) Pada Ibu Hamil Terhadap Kadar Hb Di Kelurahan Cilamajang Kec. Kawalu Kota Tasikmalaya Tahun 2016. Jurnal Kesehatan Bakti Tunas Husada; 2016: Volume 16 Nomor 1.

[14] Arisman. Gizi Dalam Daur Kehidupan. Jakarta: EGC; 2009.

[15] Waryana. Gizi Produksi. Edisi Pertama. Yogyakarta: Pustaka Rihama; 2010.

[16] Chaeril, A.R. Hubungan Pola Makan Dengan Kejadian Anemia Pada Ibu Hamil Trimester Iii Di Puskesmas Jetis Kota Yogyakarta. Naskah Publikasi. Yogyakarta: Program Studi Bidan Pendidik Jenjang Diploma IV Fakultas Ilmu Kesehatan Universitas 'Aisyiyah Yogyakarta; 2017.

[17] Abay, A., Yalew, H.W., Tariku, E And Gebeye, E. Determinants Of Prenatal Anemia In Ethiopia. Archives Of Public Health; 2017: 75:51 Doi 10.1186/S13690-0170215-7.
[18] Pertiwi, Aldila Septiana. Hubungan Antara Pola Makan Dengan Kejadian Anemia Pada Ibu Hamil Di Wilayah Kerja Puskesmas Kerjo Kabupaten Karanganyar. Naskah Publikasi. Surakarta: Program Studi Gizi Fakultas Ilmu Kesehatan Universitas Muhammadiyah Surakarta; 2013.

[19] Rahayu, L. D. P Dan Suryani, E. S. Hubungan Konsumsi Sayuran Hijau Dengan Anemia Pada Ibu Hamil Di Puskesmas Rembang Kabupaten Purbalingga. Bidan Prada: Jurnal Publikasi Kebidanan; 2018; Vol. 9 No. 1: 31-38

[20] Melorys L. P., Dan Galuh N. P. Faktor Kejadian Anemia Pada Ibu Hamil. Higeia Journal Of Public Health Research And Development. 2017; Volume 1 Nomor 3. Http://Journal.Unnes.Ac.Id/Sju/Ind ex.Php/Higeia.

[21] Masthalin, H., Laraeni, Y., Dan Dahlia, Y.P. Pola Konsumsi (Faktor Inhibitor Dan Enhancer Fe) Terhadap Kejadian Anemia Remaja Putri. Jurnal Kemas. 2015; 11 (1): 80-86 